\title{
Earnings Management: The Misapplication Of Accounting Rules And Standards
}

\author{
Kingsley Wokukwu DBA \\ Associate Professor of Business \\ School of Business. Stillman College, \\ 3601 Stillman Blvd, Tuscaloosa, Al 35401
}

\begin{abstract}
This paper discuses earnings management and also explores the role accounting standard played. The plethora of financial scandal and earnings restatements in recent years has left many investors questioning whether reported earnings can ever be free of earnings management, earnings manipulation, earnings smoothing and restatements. The paper looks at the role auditors and other external factors play in earnings management and revenue recognition. The paper finds that some of the improprieties relating to earnings management stems from an outdated accounting standards, complex corporate financing arrangements, preservation of executive compensation incentives and corporate pressure to meet earnings projections.
\end{abstract}

\section{INTRODUCTION}

The role of SEC (Securities and Exchange Commission) is to investors, maintain fair, orderly, promote efficient market, and facilitate capital formation. That means that SEC will regulate, monitor and prosecute those firms' who are breaking the SEC rules. Its rules are designed to keep financial information transparent, fair, and honest and to promote investor confidence in the financial markets and institutions. Companies offering securities for sale to the public must be transparent about their business, the securities they are selling, and the risks involved in investing in those businesses. FASB (Financial Accounting Standard Board) is established to improve the financial reporting standards of public companies, and to provide leadership for public companies in establishing and improving the financial accounting methods used in preparing financial statements. FASB develops and issues financial accounting standards through a transparent and inclusive process intended to promote financial reporting that provides useful information to investors and others who use published financial reports. FASB seeks to actively achieve this objective by facilitating an open independent reporting that allows broad participation from the firms' stakeholders. The mission of the FASB is governed by the Financial Accounting foundation (FAF) Board of Trustees. The SEC has the statutory authority to establish and manage financial reporting standard under the Securities and Exchange Act of 1934, but SEC has elected to transfer this power to the privately held FASB to self-manage the private sector.

GAAP (Generally Accepted Accounting Principles) provides a common framework for managers and accountant to use when preparing and reporting financial information. GAAP are a common rules and standards that dictates how financial statements are prepared. The role of the GAAP is to improve standards of financial reporting for the guidance and education of the public which includes companies who issue financial statements, auditors, and users of the published financial information. Transparency in financial reporting is of the essence because individuals, potential investors, creditors, and regulators make investment decisions based on firms published financial reports. One of the stumbling blocks is the seemingly diverse component of the standards, interpretations, and the application of the standards. Grover (1992) states that some big corporations are taking advantage of accounting rules to 
improve their economic outlook. These companies are taking big write-offs so that in the future they can add some of that reserve to their operating income if their initial write-off was too large. Dean (1993) postulates that corporate interests influence many of the FASB standards, along with its funding and membership. He suggests that one way to make FASB to update accounting standards and regulation is to make Securities and Exchange Commission (SEC) responsible for appointment of board members.

\section{Materiality}

The publicized accounting fraud by Qwest, Enron, Worldcom, Healthsouth now Encompass Health, Global Crossing, Adelphia, and Tyco generated media frenzy on abuses in the application of accounting rules by Accountants and Auditors who played a major role in inflating earnings to meeting market expectations within the confine of the GAAP. The GAO (Government Accountability Office) and the SEC reports expressed concern on corporate accounting improprieties that begun to surface in the late 1990's and are censorious of the magnitude of publicly held firms that restated their financial statement. The GAO report noted that the number of firms that restated their earnings is on the rise and equally disturbing. The report also states that the publicly held companies that restated their financial statements increased by $147 \%$ from January 1997 through June 2002. The GAO report says "that a number of well-publicized announcements about financial statement restatements by large, well-known public companies have erased billions of dollars of previously reported earnings and raised questions about the credibility of accounting practices and the quality of corporate financial disclosure and oversight in the United States" Industry officials and academics have speculated that several factors may have caused U.S. companies to use questionable accounting practices. Some officials have stated that increased focus and guidance by the SEC on accounting issues in the late 1990s may have prompted more companies to restate previously reported financial statements. According to the GAO report, four factors are identified as the causes why firms use questionable practices: 1) Corporate pressure to meet earnings projections and thus maintain stock prices during and after the market expansion of 1990's. 2) Perverse executive compensation incentives. 3) Outdated accounting rule based standards, and 4) Complex corporate financing arrangements. The Securities and Exchange Commission released Staff Accounting Bulletin No 99 (SAB 99) which declares that the principle-like qualitative standard that would govern financial statement. The Committee on Capital Market Regulation report in 2006 criticized SAB 99 as vague. SAB 99 does not eliminate the need for professional judgement in determining materiality. But the guidelines can help alert the auditors to a possible signs of fraud, and provides examples of acceptable and unacceptable factors to consider. Materiality plays a pivotal role in the financial reporting process. Earnings management abuses often stem from the misuse or misunderstanding of the proper application of the materiality concept.

The qualitative standard of financial reporting requires assessments of a wide range of factors which include subjective motivation for financial misstatements, and is directed at the problems of manipulation that result from a rule like quantitative standard. Aggressive corporate managers could give a sudden pinch to their earnings at will to meet market expectation. The Committee on Capital Market Regulation recommends that the Securities and Exchange Commission revise its guidance on materiality for financial reporting as it was traditionally defined in terms of a-five-percent of pretax income threshold. The qualitative and quantitative standards are the breeding ground for earnings management, restatements, and manipulation. 


\section{Manipulation}

Earnings management is a management practice or the aggressive use of accounting practices that manipulates earnings that fall within GAAP and fraudulent practice that violates GAAP. Stanley and Waldron (2007) earnings management is a deliberate action taken within GAAP to bring about desired earnings outcomes. They argue that GAAP is rule based, but the wide latitude flexibility that exists in its application, and many subjective judgments and assumptions must be made in determining accrual-based earnings. Stolowy and Breton (2003) states that accounting manipulation is the management discretionary application of accounting rules to make accounting choices that may affect the transfer of wealth between companies, the company, capital providers, the company, and the managers. Brown (1999) notes that it is precisely the application of professional use of judgement, latitude, flexibility, and subjectivity in applying GAAP that allow earnings management to flourish. Pitman (2001) defined earnings management as the use of judgment in financial reporting and in structuring transactions to alter financial reports to either mislead some stakeholders about the underlying economic performance of the company, or to influence contractual outcomes that depend on reported accounting information. The former SEC Chairman, Arthur Levitt Jr., states that earnings management is generally pursued with five accounting practices such as the big bath, restructuring charges, creative acquisition accounting, cookie jar reserves immaterial misapplications of accounting principles, and the premature recognition of revenue. Desai (2005) states that the corporate profits are the measurement that is central to capital allocation within the economy and to a variety of economic policy decisions. He argues that investors infer a company's prospects and value from reported earnings, adjusting portfolio decisions in response to changed estimates and aggregate corporate profits are often employed to forecast overall stock market. Under performing firms may be tempted to use questionable accounting techniques to boost earnings to meet market expectations, if undetected might mislead and confuse potential investors, creditors, and other users of financial statements. Earnings manipulation occur when management use judgment in financial reporting and structuring transactions to alter financial report to make earnings appear higher than they actually are. The underlying economic performances of the company are masked to mislead or influence contractual outcomes that depend on published financial statements. Schipper (1989), Lev (2003) classified earnings manipulations into three overlapping categories: personal gain, continuation of investors/suppliers support, and satisfying contractual agreements. They argue that in some cases managers manipulate earnings for personal gain because a large portion of executive compensation (stocks and stock options) is typically linked directly or indirectly to earnings. DeFond and Jiambalvo (1994) found evidence consistent with earnings manipulation by firms that violate debt covenants. Their results are consistent with a well-established hypothesis in the accounting and finance literature which indicate that managers make income-increasing accounting decisions when their firms are close to debt covenant violation. Healy (1985) documented an upward trend in earnings manipulation when pre-manipulated earnings fell within the bonus bounds of the company, and a downward trend of earnings manipulations when pre-manipulated earnings fell outside the bonus bounds, presumably to shift the "saved" earnings to future periods when they would have an impact on the bonus. Lev (2003) report that in 1990's accounting scheme helped to inflate Xerox's stock price so that the executives could cash in five millions in performance based compensation and more than thirty millions from stock sales. He argues that Xerox stock rose to more than $\$ 60$ per share in mid 1999, the period which SEC says that the Xerox's executive were manipulating earnings before the stock price fell to less that four dollars per share in 2000.

Jordan, Clark and Waldron (2007) state that one of the reasons why firms manage or manipulate earnings is to meet market expectations or forecasts by analysts. They argue that 
the companies that meet or exceed earnings expectations enjoy the benefit of higher stock prices and earnings per share relative to companies that do not meet earnings expectations. Glaum, Lichtblau, and Lindeman (2004) also indicate that that management manipulates earnings to increase their own wealth through bonus schemes tie to earnings. Brown and Higgins (2001) earnings management occurs as management seeks to enhance share-price performance because of the resultant benefit accruing to them from their stock-based compensation packages. Church at el (2001) note that earnings-based bonus plans and restrictive debt covenants can create economic incentives for managers to manipulate earnings. They argue that the objective of such behavior is to maximize the present value of bonus income and maintain compliance with debt covenants. Such behavior may involve the use of discretionary accruals and accounting changes, they may also be affected through deliberate, non-GAAP manipulations of financial data (Church, at el., 2001).

Schipper (1989) states that financial statement manipulation can be divided into two separate but often blurred categories: earnings manipulation and earnings management. He argues that the distinguishing characteristic between manipulation and management is somewhat subjective but it is generally seen as techniques used in preparing financial information that is either misleading or inaccurate. The difference according to Schipper in 1989 can rest in whether the technique used might fall within or outside the requirements and recommendations provided by Generally Accepted Accounting Principles. Goel and Thakor (2003) state that earnings smoothing is a special case of earnings management involving intertemporal smoothing of reported earnings relative to economic earnings; it attempts to make earnings less variable over time. They distinguish two types of earnings smoothing (artificial and real smoothing) and argue that real smoothing involves changing the timing of cash flows from investments and providing promotional discount, and providing financing to risk tolerant customers to boost sales. On the other hand, artificial smoothing involves the use of flexibility afforded by the General Accepted Accounting Principal to attain desired level of sales. Jackson and Pitman (2001) argue that earnings management represents purposeful intervention in the financial reporting process with the intent of obtaining personal gains.

Arthur Levitt the former chairman of SEC (1998), states that "the practice of management of earnings should be abolished for the sake of our markets; for the sake our global economy which depends so much on the reliability of America's financial system; for the sake of investors; and for the sake of a larger commitment not only to each other, but to ourselves. A version of earnings management that has become far more common in recent years is the reporting of 'pro forma earnings' measures. These measures are called or referred to as operating earnings; a term with no generally accepted definition. The pro forma earnings statements are calculated ignoring certain expenses such as restructuring charges, stockoptions expenses or write-down of assets from continuing operations. Management believes that by ignoring these expenses, a clearer picture of the underlying profitability of the firm will emerge. Ross (2005) points out that the corporate executives are allowed to use judgment to determine amounts reported on accounts that greatly affect resulting financial information. Stanley and Waldron (2007) state that earnings management can be accomplished because the determination of accrual earnings under GAAP is subject to numerous estimate and judgments in accounting policy choice SFAS No 143 (Statement of Financial Accounting Standards No 143). There is so much leeway for choosing what to exclude or include that it becomes difficult for investors and analysts to interpret the numbers across firms. The lack of clearly to a defined standards give management leeway to manipulate earnings. GAAP allows firms considerable discretion to manipulate earnings. David and Geoff (1991) note that, it is precisely this subjectivity in applying GAAP that allows earning management to flourish in firms. 
Jackson and Pittman (2001) argue that there is a growing concern in the investment community that certain practice of earnings management are eroding public confidence in external financial reporting and impeding efficient flow of capital in financial market. In September 28, 1998 in a Number Game Speech, the former SEC Chairman, Arthur Levitt Jr. (1998) expressed his concern that failure of corporate managers to provide meaningful and representative financial information on their financial statement erodes not only the trust between stockholders and the company, but also threatens our economy with subsequent price fluctuations. He states that too many corporate managers, auditors, and analysts are participants in a game of nods and winks. Later in his speech he emphasizes concern for the American economy, and argues that the current culture among the corporate managers, auditors, and analysts and their credibility has been called into question. He calls on independent auditors to lead the crusade to prevent deceptive accounting practices because of their in-depth knowledge of accounting and reporting matters but also have access to audit committee and the board of directors responsible for scrutinizing a company's decision makers. He expressed his concern of witnessing the erosion in the quality of earnings, and therefore, the quality of financial reporting, and uniformly agreed accounting misrepresentations, which ensues among them, undermines the integrity and the number one position of the American financial market in the world. Levitt believes that the earnings management scheme negatively influences the accuracy of company's financial statements will eventually, if not addressed soon yield to the erosion of faith in capitalism as a viable solution to the efficient allocation of resources in our societies.

Following the demise of Enron and other corporations, the US accounting profession is rushing to restore confidence to the investing public. In late October 2002, FASB issued a proposal for public comments on a principles-based approach to accounting setting, this might improve the quality and transparency of financial reporting. The FASB Chairman Robert Herz says FASB is committed to improving U.S. financial accounting standards. Chairman Robert Herz states that "Many believe that moving to a broader or more principles based accounting standards as those used in other parts of the world would facilitate better reporting in the United States" Quinn

(2003) argues that Principles-based approach to accounting could reduce the comparability of financial information and leave too much room for judgment by companies and auditors. SAS No 82 (Standard of Auditing Standard) requires auditors to specifically assess risk of material misstatement from fraud. SAS No. 82 also states that the auditor has the responsibility to plan and perform the audit to obtain reasonable assurance about whether the financial statements are free of material misstatement caused by error or fraud. SAS No 82 distinguishes fraud from error on the basis of whether the underlying actions of the corporate managers that result in a misstatement of financial statement is intentional or unintentional.

\section{Accruals}

Securities and Exchange Commission, Staff Accounting Bulletin SAB 101 provides the guidelines for revenue recognition, income statement presentation and requires disclosures concerning revenues in financial statements. Firms go as far as they can to recognize revenues that lack economic substance; realization principle requires that two criteria be satisfied before revenue is recognized. 1 The earnings process is judged to be complete or virtually complete. 2 . There is reasonable certainty as to the collectivity of the asset. Stated alternatively revenue can be recognized only after the earnings process is virtually complete and collection from the customer is reasonably assured. Revenue recognition guidelines by nature could be controversial and strictly adhering to the criterion would violate the overriding objectives of revenue recognition principles in the period revenue generating activities of the company are 
performed. On May28, 2014 the FASB (Financial Accounting Standard Board) and IASB (International Accounting Standard Board) jointly adapted a converged accounting standard on Revenue Recognition. The new Revenue Recognition replaces nearly all US GAAP and International Financial Reporting Standard (IFRS) guidelines that require significant flexibility and changes in the way US companies recognize revenue in their financial statements. The new revenue standard will significantly affect the revenue recognition practices of most companies. The new revenue recognition standard provides a comprehensive, industry-neutral revenue recognition model intended to increase financial statement comparability across companies and industries. This standard applies to companies across all industries to use a new five-step model to recognize revenue from customer contract. The new revenue standard requires any company or business that enters into a contract with customers to transfer goods or services into a contract for the transfer of nonfinancial assets, unless the contract are within the scope of other standards. The new standard International Accounting Standard Board (IASB) IFRS 15 and US Based Financial Accounting Standard Board (FASB) ASU 2014-09 is as a result of a convergence project between the two Boards. Green (2003) notes that understanding when revenues are recognized is the first step to comprehending the quality of the revenue stream. He argues that revenues of the highest quality are those that are recognized after the customer has received, accepted, and paid for the product or services without any further performance requirements or contingency. The SEC former chairman, Arthur Levitt (1998) identified revenue recognition guidelines as a popular way for companies to manage earnings prematurely. He argues that premature revenue recognition reduces the quality of reporting earnings, particularly, if those revenues never materialized. Corporate executives tend to believe that by manipulating earnings and presenting fraudulent financial report to meet predetermined level of earnings would increase firm value, earnings per share, market price per share and favorable bond rating. This may have short-term effect but on the long run it will have an exact opposite effect on firm value etc. Sarbanes -Oxley Act examines the role of board of directors in constraining earnings management.

(Klein 2002). Sarbanes -Oxley Act enacted provisions that deal with the rules governing corporate governance in general and the board of directors in particular that should likely constraint earnings manipulation. Sarbanes-Oxley Act reiterates the importance of ensuring that financial statements are free of material misstatements due to error or fraud. The Sarbanes -Oxley Act is the most sweeping regulatory reform since the creation of SEC in 1943. The Act mandates the SEC to regularly and systematically review the disclosures of companies that have securities on a national securities exchange, and particularly those firms that have issued material restatements of financial results or those that have experience significant volatility in their stock price as compared to other listed companies. The Act also mandates that each period, financial statements report should be accompanied by a written statement by issuer's Chief Executive Officer and Chief Financial Officer certifying that the report fully complies with the 1934 Security Act and the information contained in the periodic report "fairly presents, in all material respects, the financial condition, and results of the issuer. PCAOB (Public Company Accounting Oversight Board) notes in the alert that misstatement of revenue is a common ploy in many financial fraud cases. According to PCAOB a 2010 report of a-ten-year study by the COSCO (Committee of Sponsoring Organization of the Tradeway Commission) of Accounting and Enforcement Action by Security Exchange Commission found that $61 \%$ of 347 cases involve gaming or fabricating revenue, the most common method used to improve the appearance of financial statements. Fama and Jensen (1983) argue that separating the positions of chief executive officer and the chairman of the board would improve board monitoring and organizational performance by providing an independent check on the chief executive officer position. They further state that firms that have the same person 
holding these two positions are less likely to have effective monitoring which reduces the likelihood of constraining earnings manipulation.

Visvanathan (2008) reports that much attention has been focused upon the role of the board of directors and audit committees, in overseeing the activities of corporate executives in particular instances of earnings manipulations. Management can significantly alter the earnings to deceive the investors and Wall Street that earnings or certain financial goals have been met. Visvanathan (2008) says that much of the attentions are focused on accrual type earning management such as aggressive revenue recognition, misstatement of inventories and accounts receivable. Accounts

receivables should be recorded at the present value of accounts receivable of future cash receipts using realistic discount rate or interest rate. However, because the difference between present and future of accounts receivable often is immaterial, therefore APB 21 specifically excludes accounts receivable from the general rule that receivable be recorded at present value. The accounts receivable is initially valued at the exchange price agreed upon by the buyer and seller. Ross (2005) states that in many cases of fraud, companies try to manage their appearance by inappropriately reporting fictitious revenue and by failing to report to expenses as they occur. He argues that without egregious transgressions, companies can take full advantage of two types of legitimate latitudes, operational freedom and reporting freedom accorded them by the Generally Accepted Accounting Principles.

\section{CONCLUSION}

Firms are able to utilize earnings management to inflate profits because of the faulty design in GAAP. Earnings management of a material amount constitutes fraudulent financial reporting and should be vigorously addressed by auditors and regulators. One of the pitfalls is to allow companies to report revenues that have not been earned which is referred to as pooling-ofinterest method of accounting. This method allows a business to report higher earnings without having to earn them. Earnings guidelines based on relevant financial accounting support is vital to all publicly held companies. Earnings management undermines earnings quality, erodes transparency in financial reporting and misleads users of financial statements. The financial reporting problems exist because the Financial Accounting Standard Board have not kept up with changing business arena and the standard allow for use of judgment in managing earnings. The reporting problems can be classified as recognition or measurement problems. Companies who fail to meet financial market expectations are penalized by the market. They see their stock price drop precipitously. They are victims of market reaction for not meeting financial market expectation. Some of the accounting improprieties related to earnings management are not perpetrated by the corporate managers alone; in-house accountants, Chief Financial Officers and Independent Auditors all play vital roles in earnings management. The actions of Wall Street official also contributed to the problem by lobbying for the Private Security Act of 1995. The Act made it more difficult to sue executives and auditors for fraud. Financial market tend to disregard big non-operating charges by the management thereby creating an avenue for mangers to big charges and in the circumstance manipulates earnings. To combat earnings management practices, the management and the board of directors should investigate how realistic the expectation about the firm from the financial market and the analyst are. 


\section{References}

Abbott, L.J.,S.Parker \& G.F. Peters (2004). Audit committee characteristics and restatements. Auditing: A Journal of Practice \& Theory 23 (March): 69-87.

Anan Mohan Geol \& Anjan V., Thakor (2003) Why do firms smooth earnings, Journal of Business Vol 75 No 1, 151192.

Beasley, M. (1996). An empirical analysis of the relation between the board of director composition and financial fraud. The Accounting Review 71 (4): 443-65.

Brown P. R.(1982) FASB Responsiveness to Corporate input, Journal of Accounting , Auditing, and Finance (Summer) 282-290.

Chai, M.L. \& S. Tung (2002). The effects of earnings-announcement timing on earnings management. Journal of Business Finance and Accounting, 29(9/10), 1337-1354.

Church, K. B., Mcmillian, J. J \& Schneider, A. (2001). Factors Affecting Internal Auditors' Consideration of Fraudulent Financial Reporting during Analytical Procedures. Auditing: A journal of Practice and Theory v20 i1 65.

Collingwood, H. 2001. The earnings game: everyone plays, nobody wins. Harvard Business Review 79 (June): $65-$ 77.

Copeland, T.E. \& J.F. Weston (1980). Financial Theory and Corporate Policy, (Third Edition). Menlo Park, CA: Addison-Wesley Publishing Co., 196-198.

Dailey, L. P \& Poteau R. R. (1994). “Accounting Rule Making: A Two Headed Monster?” CPA Journal, (June) 28-31.

Daniel M. Beneish, Charles M. C. Lee, Craig D. Nichols (2013) Financial Analysts Journal. Accounting. Vol. 69. Issue 2. 57-82

Davis, J. R., (1989) Ambiguity, ethics, and the bottom line. Business Horizons (May-June) v32 n3 65(6)

David, T \& Geoff, W. Financial Reporting Problems Solutions via Reform. Accountancy, (March) 78-82

Dean F. (1993). "It's Time to Free the FASB Seven” Business Week (May) 144.

Dechow, P. M. 1994. Accounting earnings and cash flows as measures of firm performance: The role of accounting accruals. Journal of Accounting and Economics 18 (July): 3-42.

Dechow, P., R. Sloan \& A. Sweeney (1996). Causes and consequences of earnings manipulations: An analysis of firms subject to enforcement actions by the SEC. Contemporary Accounting Research 13 (1): 1-36.

Defond, M. L., and Park, C. W. 1997. Smoothing income in anticipation of future earnings. Journal of Accounting and Economics 23 (July): 115-39.

DeFond ML, Jiambalvo J (1994) Debt covenant violation and manipulation of accruals. J Account Econ 17:145-176.

Degeorge, F., J. Patel, \& R. Zeckhauser (1999). Earnings management to exceed thresholds. Journal of Business, 72(1), 1-33.

Desai Mihir A (2005) The Degradation of Reported Corporate Protits. Journal of Economic Perspectives. Vol. 19 11(4) 171-192

DeZoort, F.T., D.R. Hermanson, D.S. Archambeault \& S.A. Reed (2002). Audit committee effectiveness: a synthesis of the empirical audit committee literature. Journal of Accounting Literature 21: 38-75.

Dye, R.A. 1988. Earnings management in an overlapping generations model. Journal of Accounting Research 26 (Autumn): 195-235

Elliot, J.A. \& W.H. Shaw (1988). Write offs as accounting procedures to manage perceptions. Journal of Accounting Research, 26 (supplement), 91-119.

Ewert, R., \& Wagenhofer (2005) Economic effect of tightening accounting standard to restrict earnings management. The Accounting Review, 80(4), 1101-1124.

Fama, E. \& M. Jenson (1983). Separation of ownership and control. Journal of Law and Economics 26, 301-326.

FASB (2001). Reporting information about the financial performance of business enterprises: Focusing on the form and content of financial statements.

FASB (2005). SFAS No. 154, Accounting changes and error corrections. 
FASB (2009). Financial statement presentation--Joint project of the IASB and FASB.

Fudenberg, D., and Tirole, J. 1995. A theory of income and dividend smoothing based on incumbency rents. Journal of Political Economy 103 (February): 75-93.

GAO Financial Restatement Database (GA0-06-1079sp)

Gitman L. J \& Zutter C J (2010) Principles of Managerial Finance 3th Ed.

Glaum, M.,K. Litchtblau, \& J. Lindeman (2004). The extent of earnings management in the U.S. and Germany. Journal of International Accounting Research, 3(2), 45-77.

Gnanakumar Visvanathan. (2008). Corporate governance and real earnings management. Academy of Accounting and Financial Studies Journal v12 i1 P9 (14).

Goel M. A. \& Thakor A. V (2003) Why Do Firms Smooth Earnings. Journal of Business Vol 76, No1 (January) $151-$ 192

Government Accountability Office (2002) Letter to Honorable Paul S. Sarbanes dated October 4 retrieved from http://www.gao.gov/d03138

Graham, J.R., C.R. Harvey \& S. Rajgopal (2005). The economic implications of corporate financial reporting. Journal of Accounting and economics 40, 3-73.

Guidry, F.,A.J. Leone, \& S. Rock (1999). Earnings-based plans and earnings management by business-unit managers. Journal of Accounting and Economics, 26(Jan.), 113-142.

Graham, J., C. Harvey \& S. Rajgopal (2005) The economic implications of corporate financial reporting. Journal of Accounting \& Economics, 40(1-3), 3-73.

Green (2003) Fighting financial reporting fraud. Internal Auditor v60 i6 p58(7).

Griffin, R.B., R.L. Putman, E.R. Moser \& R.W. Kilgore (2006). The ethics dilemma: Are AACSB accredited business programs doing their part in helping reestablish confidence in the free enterprise system? The Journal of Learning in Higher Education, 2(2), 53.

Griffin, R.B., E. Joyner, E. Moser, \& B. Putman (2007). An overview of undergraduate accounting education in AACSB accredited accounting programs. Journal of Business and Economic Perspectives, XXXIIII (2) (forthcoming).

Griffin, R.B., B.W. Griffin \& R.L. Putman (2008). Is there uniformity in the education requirements of boards of accountancy to sit for the Uniform certified public accounting exam? International Journal of the Academic Business World, II (Spring 2008), (forthcoming).

Grover M. B. (1992) “Generally Vague Accounting Principles” Forbes (September) 462-464.

Healy, P.M. (1985). The effect of bonus schemes on the selection of accounting principles. Journal of Accounting and Economics, 7 (Apr.), 85-107.

Hermalin, B. \& M. Weisbach (2003). Boards of directors as an endogenously determined institution: A survey of the economic literature. Economic Policy Review 9 (1): 7-26.

Herrman, D., T Inoue, \& W. B. Thomas (2003) The sale of assets to management earnings in Japan. Journal of Accounting Research. 41(1), 89-108

Jackson, S. \& M. Pitman (2001). Auditors and earnings management. The CPA Journal, 71(7),39-44.

James , R. Davis (1989). Ambiguity, Ethics, and the Bottom Line. Business Horizon v32n3 p(65)6.

Jennings, M.M. (2004). Incorporating ethics and professionalism into accounting education and research: A discussion of the voids and advocacy for training in seminal works in business. Issues in Accounting Education, 19(1), 7-26.

Jenson, M. (1993). The modern industrial revolution, exit, and the failure of internal control systems. Journal of Finance 48 (3): 831-880.

Jiambalvo, J.; Rajgopal, S.; and Venkatachalam, M. (2002). Institutional ownership and the extent to which stock prices reflect future earnings. Contemporary Accounting Research 19 (Spring): 117-45.

John A. Fogarty, Lynford Graham, and Darrel R. Schubbert (2006). Assessing and Responding to Risk in a Financial Statement Audit: Auditors Must Leave a Clear Record in a Private Company Audits. Journal of Accountancy. 
Jordan, C.E. \& S.J. Clark (2003). Evidence on the level of corporate America's participation in the earnings game. The National Accounting Journal, 5(1), 61-70.

Jordan, C. E., Clark, S. J., \& Waldron (2007) Company characteristics and the use of SFAS No. 143 to affect earnings management. Academy of Accounting and financial Studies Journal (May) v11 i2 97(11)

Karim S. Rebeiz. (2007). How to contain the management of Earnings? The insider's Perspective. Review of Business Research. v7 i6 P9(8)

King, A. M. (1992) “GAAP financial statements: Turning Myths into Reality” Business Credit, (NovemberDecember) 33-36.

Klein, A. (2002a). Audit committee, board of director characteristics, and earnings management. Journal of Accounting and Economics 33 (3): 375-400.

Klein, A. (2002b). Economic determinants of audit committee independence. The accounting Review 77(2):43552.

Kreps, D. M., and Wilson, R. 1982. Sequential Equilibria. Econometrica 53 (January): 863-94.

Kyle, A. s. 1985. Continuous auctions and insider trading. Econometrica 53 (November): 1315-36.

Laffont J. J., \& Triole J., (1991) The politics of Government Decision making: A Theory of Regulatory Capture. Quarterly Journal 106(4) 1088-1127

Largay, J.A. \& C.P. Stickney (1980). Cash flows, ratio analysis, and the W.T. Grant Company Bankruptcy. Financial Analysts Journal, July-August, 51-54.

Leonard, G. W., Peter, M. B., Lorraine, M. (2004) Anatomy of A Financial Fraud. CPA Journal

Lev B (2003). Corporate Earnings: Facts of Fiction. Journal of Economic Perspective. Vol 17 No 2 (Spring) 27- 50

Levitt, A (1998) The numbers game. Remarks Delivered at New York University Center for Law and Business. New York, NY September 28.

May, G.S. \& D.K. Schneider (1988). Reporting accounting changes: Are stricter guidelines needed? Accounting Horizons, 2(3), 68-74

McConnell K. D., G. Y. Banks (1997). The New Fraud Audit Standard. The CPA Journal v67 n6 22(7).

Menon, K. \& J.D. Williams (1994). The use of audit committees for monitoring. Journal of Accounting and Public Policy 13 (Spring): 121-139.

Mihir A Desai (2005). The Degradation of Reported Corporate Profits. The Journal of Economic Perspectives Vol. 9. No 4. P 171-192.

PCAOB 2014 Issues New Alert on Revenue Recognition.

Payne, J.L. \& S.W.G. Robb (2000). Earnings management: The effect of ex ante earnings expectations. Journal of Accounting, Auditing, and Finance, 15(4), 371-392.

Peek, E. (2004). The use of discretionary provisions in earnings management: Evidence from the Netherlands. Journal of International Accounting Research, 3(2),27-43.

Penno, M. \& D. Simon (1986). Accounting choices: Public versus Private firms. Journal of Business Finance and Accounting, 13(4), 561-569.

Porcano, T.M. (1997). An analysis of capital gains tax-induced earnings management. International Advances in Economic Research, 3(4),395-408.

PricewaterhouseCoopers. (2000). Audit Committee Effectiveness-What Works Best. Institute of Internal Auditors Research Foundation.

Quinn, L. R. (2003). The rules explosion: Is It Time to Move Towards Principles. Strategic Finance (January) v84 i7 39(5)

Raghunandan, K., W.J. Read \& D.V. Rama. (2001). Audit committee composition, "gray directors", and interaction with internal auditing. Accounting Horizons 15 (June):105-118.

Richard B., Griffin; Robert L. Putman; \& Ronald W. Kilgore (2009). The impact of earnings management on capital market: ethical consideration of the players. Journal of Legal and Regulatory Issues Vol. 12 iL 113-121

Robert K. Herdman (2002) Speech by SEC Staff: Rule Proposal in Connection With the Establishment of A Framework of a Public Accountability Board. U. S. Securities and Exchange Commission. 
Robert L. Putman, Richard B. Griffin and Ronald W. Kilgore (2009) The impact of earnings management on capital market: ethical consideration of the players. Journal of Legal, Ethical and Regulatory Issues v12 i1 P113(8)

Roychowdhurt, S. (2006) Earnings management through real activities manipulation. Journal of Accounting \& Economics 42 (December) 335-370

Securities and Exchange Commission (SEC) (1999), Materiality. SEC Staff Accounting Bulletin No 99. Washington D.C.: Government Printing Office.

Schipper, K. (1989) Principles-based accounting standard. Accounting horizons, 17(1), 61-72

Scott B. Jackson \& Marshall K. Pitman (2001) Auditors and Earnings Management, CPA Journal Vol 71 i7 1-8

Shastri, T \& E, W Gist (2003) Revisiting materiality. The CPA Journal (November) v73 i11 60(4).

Shrieves, Ronald E. and Gao, Pengjie, Earnings Management and Executive Compensation: A Case of Overdose of Option and Underdose of Salary? (July 29, 2002). EFA 2002 Berlin Meetings Presented Paper. Available at SSRN: $\underline{\text { https://ssrn.com/abstract=302843 }}$ or http://dx.doi.org/10.2139/ssrn.302843

Stanley and Waldron (2007) An Analysis Of The Comparative Abilities Of Cash Flows, Earnings, And Sales. Journal Of Applies Business Research. Vol. 23 P. 53-74.

Soon Suk Yoon; Hyo Jin Kim. (2009). Earnings Management Practices For Venture IPO Firms. Academy of Accounting and Financial Studies Journal v13 i12 P47 (21).

Souichi Matsuuru. (2008). On the relation between real earnings management and accounting earnings management: income smoothing perspective. Journal of International Business Research v7 i3 P63(15)

Stanley. (2004). Incorporating ethics and professionalism into accounting education and research: A discussion of the voids and advocacy for training in seminal works in business. Issues in Accounting Education, 19(1), 7-26.

Stolowy H., Breton G. (2004). Accounts Manipulation: a literature review and proposed conceptual framework, Review of Accounting and Finance, Vol. 3, No. 1.

Sweeney, A.P. (1994). Debt-covenant violations and managers' accounting responses. Journal of accounting and Economics, 17(3),281-308.

Thomas J. Phillips Jr., Andrea Drake, Michael S. Luehlfing (2010).Transparency in financial reporting: a look at rules-based versus principles-based standards. Academy of Accounting and Financial Studies Journal. Oct 2010 v14 i4 p11(18)

Vasarhelyi, Miklos A., Kogan Alexander, \& Alles Michael G.(2002) Would continuous auditing have prevented the Enron Mess? The CPA Review v72 i7. 80 (1)

Visvanathan, G. (2008). Deferred tax valuation allowances and earnings management. Journal of Financial Statement Analysis, 3(4), 6-15.

Walter, S. (1991). “Keep It Simple.” Accounting Horizon, (June) 113-117.

Watts, R.L. \& J.L. Zimmerman (1986). Towards a positive theory of the determination of accounting standards. The Accounting Review, 53(1), 112-134.

Wu, M. 2002. Earnings restatements: A capital markets perspective. Working paper, New York University.

Yermack, D. (1996). Higher market valuation companies with a small board of directors. Journal of financial Economics 40, 185-212.

Yoon, S.S. \& G.A. Miller (2002). Cash from operations and earnings management in Korea. International Journal of Accounting, 37(4), 395-412.

Zeff, Steven A. (2003). How the accounting profession got where it is today: Part I. Accounting Horizons, 17(3), 192. 